Original Paper http://ajol.info/index.php/ijbcs http://indexmedicus.afro.who.int

\title{
Physicochemical and pasting properties of some local and improved maize varieties cultivated in Benin
}

\author{
Fresnellia S. Y. SAGBO ${ }^{1}$, M. Vahid AÏSSI ${ }^{1,2}$, Waliou Amoussa HOUNKPATIN ${ }^{3}$, \\ Célestin HOUEDO ${ }^{1}$, Alexandre DANSI ${ }^{4}$ and Mohamed M. SOUMANOU ${ }^{1 *}$ \\ ${ }^{1}$ Unité de Recherche en Génie Enzymatique et Alimentaire, Laboratoire d'Étude et de Recherche en Chimie \\ Appliquée, École Polytechnique d'Abomey-Calavi, Université d'Abomey-Calavi, 01 BP 2009 Cotonou, Bénin. \\ ${ }^{2}$ École des Sciences et Techniques de Conservation et de Transformation des Produits Agricoles, \\ Université Nationale d'Agriculture, BP 114 Sakété, Bénin. \\ ${ }^{3}$ Département de Nutrition et Sciences Alimentaires, Faculté des Sciences Agronomiques, Université \\ d'Abomey-Calavi, BP 526, Cotonou, Bénin. \\ ${ }^{4}$ Laboratoire de Biotechnologies, Ressources Génétiques et Amélioration des Espèces Animales et Végétales, \\ Faculté des Sciences et Techniques de Dassa, Université Nationale des Sciences et Technologies, Ingénierie et \\ Mathématiques, Dassa, Bénin. \\ ${ }^{*}$ Corresponding author; E-mail: msoumanoufr@yahoo.fr, mohamed.soumanou@epac.uac.bj, \\ Tel.: 0022997877870
}

\section{ACKNOWLEDGEMENTS}

This work was financially supported by the West African Agricultural Productivity Project (WAAPP) Benin and scholarship obtained by the first author through PPAOA is highly acknowledged.

\begin{abstract}
Physicochemical and pasting properties of eighteen varieties of maize cultivated in Benin were investigated. Studied varieties were of various colors including red, yellow and white. Eleven varieties were more likely white, while all the white varieties had a yellowish saturation index. Moisture, fat and ash contents ranged from 6.09 to $11.57 \%, 2.87$ to $12.54 \%$ and from 1.09 to $5.46 \%$ respectively. Varieties Gnonli and $\mathrm{IWDC}_{2} \mathrm{SynF}_{2}$ showed respectively the lowest $(22.58 \%)$ and the highest $(26.86 \%)$ amylose contents. The pasting properties of the maize flours showed significant differences $(\mathrm{p} \leq 0.05)$ between pasting parameters (peak, final viscosity, setback, pasting temperature and peak time) among the different varieties. The results of correlations between some physicochemical characteristics of maize and their pasting properties could be used to predict their behaviors and their potential for processing into different valuable products.

(C) 2017 International Formulae Group. All rights reserved.
\end{abstract}

Keywords: Zea mays, varieties, flour, proximate composition, viscosity.

\section{INTRODUCTION}

Cereals are widely used for human consumption and animal food throughout the world. Among cereals, maize, rice and wheat constitute together the most important item in the human diet, accounting for an estimated $42.5 \%$ of the world's food energy intake (FAO, 2016). Maize (Zea mays L.) is the third 
most important cereal crop and a major source of energy and nutrients (Jompuk et al., 2011). However, it's production is sensitive to change in climatic conditions, i.e., precipitations, temperature (Saar et al., 2011) Thus, high performance (drought or wet resistant) maize varieties introduced in developing countries of Africa can help to reduce the vulnerability of countries to climate variability.

The improved maize varieties were introduced due to their good yields performances and tolerance to drought and floods (FAO, 2016). Nowadays, in many West African countries, local and improved varieties are grown by farmers. Both of the two types of varieties are consumed through several products identified (Sodjinou et al., 2008) in food consumption systems of Benin. These varieties do not necessarily have a good nutritional value. So, there is a need to study their physicochemical properties as their physical and technological characteristics start to be investigated by Semassa et al. (2016). Furthermore, Songre-Ouattara et al. (2015) studied the grain quality and food processing aptitude of eight maize varieties from Burkina Faso.

Maize varieties are interesting according to their nutritional profile. It consists especially in high contents of carbohydrates with starch being the most abundant component and secondarily in interesting protein content and other nutrients. Corn starch is a valuable ingredient to the food industry, being widely used as a thickener, gelling agent, bulking agent and water retention agent (Singh et al., 2003). Normal starch consists of about $75 \%$ branched amylopectin and about $25 \%$ amylose, that is linear or slightly branched (Karim et al., 2000). Most cereal normal starches contain in addition to amylose and amylopectine, lipids which have significant impacts on the pasting property of the starch (Horstmann et al., 2016). Cissé et al. (2013) have characterized the pasting properties of starches from different maize and observed considerable variability in these properties. In order to orientate the use of maize in food processing, there is a need to have knowledge of their physicochemical properties and to assess the pasting properties of the flour. The present study aims to investigate the relationship between physicochemical characteristics and pasting properties of some local and improved maize varieties cultivated in Benin.

\section{MATERIALS AND METHODS}

Maize materials and sample preparation

Table 1 shows the eighteen (eleven improved and the seven local) varieties of maize which were used in this study. The improved varieties were obtained from the Centre de Recherche Agricole CRA-Nord (CRAN) of the Institut National des Recherches Agricoles du Bénin (INRAB) in Borgou province of Benin Republic. The local varieties were collected from the center of maize seeds supply for the farmers. The center is located in the commune of Djidja in Zou province of Benin Republic.

Each variety of maize was grounded into uniform flour using an electric blender. The flour was used to determine the physicochemical and the pasting properties of the maize.

\section{Color determination}

The color of maize samples was determined using a Chromameter Minolta CR 400 Chroma by measuring the Hunter parameters $\mathrm{L}^{*}, \mathrm{a}^{*}$ and $\mathrm{b}^{*}$ value. The redness and the yellowness of maize varieties, were respectively expressed by $a^{*}$ and $b^{*}$ values. The lightness or brightness is explained by $\mathrm{L}^{*}$ value.

\section{Proximate analysis}

The proximate composition of the different varieties of maize was determined according to the methods described by the Association of Official Analytical Chemists (AOAC, 1990). Thus, crude protein ( $\mathrm{N}$ x 6.25 by Khejdal), fat (Hexane extract by soxhlet), ash, moisture contents and fiber of maize samples were determined. Total carbohydrates were calculated by difference. 
Apparent amylose content determination

The Apparent amylose content of the maize varieties was measured using the standard iodine colorimetric method ISO 6647-2-2011 described by Juliano (1971). A volume of $1 \mathrm{~mL}$ of Ethanol (95\%) and $9 \mathrm{~mL}$ of sodium hydroxide (1N) was added to $100 \mathrm{mg}$ of maize flour samples. The whole was mixed and heated in a boiling water bath until gelatinization of the starch occurred. After cooling, $1 \mathrm{~mL}$ of acetic acid and $2 \mathrm{~mL}$ of iodine solution were added and the volume made up to $100 \mathrm{~mL}$ with Millipore water. The iodine solution was prepared by dissolving $0.2 \mathrm{~g}$ of iodine and $2.0 \mathrm{~g}$ of potassium iodide in $100 \mathrm{~mL}$ Millipore water. The absorbance of the solution was measured using an Auto Analyzer 3 (Seal Analytical, Noderderstedt, Germany) at $600 \mathrm{~nm}$.

\section{Pasting properties}

The flour pasting properties of the maize varieties were determined with the rapid visco-analyser (RVA Model Super 4, Newport Scientific, Australia). Twenty-five $\mathrm{mL}$ of distilled water was added on $3 \mathrm{~g}$ of each maize flour sample into the test tube. The whole was mixed at $960 \mathrm{rpm}$ for $30 \mathrm{~s}$ and then at $160 \mathrm{rpm}$ during a controlled heating and cooling process under constant shear in the RVA. The temperature increased from 50 to $95^{\circ} \mathrm{C}$ in $2 \mathrm{~min}$ and subsequently cooled to 50 ${ }^{\circ} \mathrm{C}$ in $2 \mathrm{~min}$. The flour pasting properties were characterized using the RVA parameters measured including trough, peak time, setback, pasting temperature, peak temperature, and final viscosity. The flour pasting test process lasted for $13 \mathrm{~min}$.

\section{Statistical analysis}

The data collected were analyzed by one-way analysis of variance (ANOVA). Differences in means were compared using Duncan's multiple range tests using the Statistical Package for Social Scientists (SPSS for windows version 16.0). A significant level of $\mathrm{P}<0.05$ was used. Principal Component Analysis was performed on the means of the proximate composition and the flour pasting properties of the maize variety using Minitab 14.

Table 1: Maize varieties tested.

\begin{tabular}{ccc}
\hline & Name & Color \\
\hline \multirow{4}{*}{ Improved varieties } & IWDC $_{2}$ SynF $_{2}$ & White \\
& TZEE-W & White \\
FAABA QPM & White \\
DTSTRC3 Syn F2 & White \\
AK 94 DMRESR-Y & Yellow \\
DMRE SR-W & White \\
2000 Syn - EEW & White \\
TZPB & White \\
EVDT 97 STR & White \\
TZL Comp4 & White \\
DMRESR - QPM & White \\
\hline Gnonli & White \\
Fonkouin & White \\
Kpatchakpatcha & White \\
Gbadé vovo & Yellow \\
Gounvè & Red \\
Tchankpo & White \\
Tchèvè & White \\
\hline
\end{tabular}




\section{RESULTS}

\section{Color characteristics of maize grains}

Figure 1 shows the color parameters of the different maize varieties. Values of $\mathrm{L}^{*}, \mathrm{a}^{*}$ and $\mathrm{b}^{*}$ ranged from 40 to about 80 , from 8 to 25 and from 0 to 15 respectively. The variety Gnonli had the highest lightness (79.82). The red saturation index $\mathrm{a}^{*}$ is high for the variety Gounvè (13.52). A high yellowness was observed in the varieties AK-94 DMRESR-Y (23.82), Tchèvè (22.45) and Gbadé vovo (19.68).

\section{Physicochemical characteristics of maize varieties}

The proximate composition of the maize varieties analyzed in this work is presented in Table 2. Moisture contents ranged from $6.09 \%$ in Gbadé vovo to $11.57 \%$ in TZL Comp4 and varied among maize varieties. The improved varieties had moisture contents higher than the local varieties. The maize varieties studied also varied significantly in fat content which ranged from $2.87 \%$ in Gnonli to $12.54 \%$ in EVDT 97 STR. Protein contents of the maize varieties were within the range $7-12 \%$. The lowest protein content was found in the improved variety TZEE-W when the highest protein content was found in the local maize variety Gnonli. Ash contents ranged from $1.09 \%$ in 2000 Syn - EEW to $5.46 \%$ in Gbadé vovo. There was no significant difference in ash contents of the improved varieties $(\mathrm{P} \leq 0.05)$. The crude fiber of flours from the maize varieties ranged from $0.010 \%$ (Tchankpo) to $0.0365 \%$ (DTSTRC $_{3}$ Syn $\mathrm{F}_{2}$ ). Generally, the crude fiber of flours from local varieties was lower than that in the improved varieties. Although varieties varied considerably in the carbohydrate contents (64.19-78.28\%), the amylose content of flours from the maize varieties did not varied significantly ranging between 22 and $27 \%$ as shown in Table 2. Variety Gnonli had the lowest amylose content (22.58\%) and IWDC2
$\mathrm{SynF}_{2}$ had the highest $(26.86 \%)$. It can be noted that local varieties had the lowest amylose content and improved varieties had the highest.

\section{Pasting properties of maize flours}

The pasting properties of maize flours from the eighteen varieties are presented in Table 3. The peak viscosity, that is the maximum viscosity attained during the heating cycle ranged from $438 \mathrm{cP}$ (Fonkouin) to $1271.5 \mathrm{cP}$ (DMRE SR-W) and varied significantly among maize varieties. The improved varieties had higher peak viscosity than those of local varieties. Through viscosity (hot paste viscosity) values ranged from 439 to $1066 \mathrm{cP}$ while those of the final viscosity (cold paste viscosity) ranged from $800 \mathrm{cP}$ (Fonkouin) to $3521.5 \mathrm{cP}$ (DMRE SR$\mathrm{W})$. Final viscosities of the different maize varieties studied were significantly higher than peak viscosities.

The setback values of the flour from the maize varieties studied varied from 362 to $2534 \mathrm{cP}$. The pasting temperatures of maize varieties studied ranged from 78 to $85.825{ }^{\circ} \mathrm{C}$. Peak time varied from 4.6 to $7 \mathrm{~min}$. Except for the variety Gnonli which showed the lowest value, the local varieties studied had a peak time higher than that of the improved varieties.

\section{Relations between physicochemical parameters and pasting properties of maize varieties}

Principal Component Analysis (PCA) was done to detect the correlations between variables. The correlations between the color parameters, the physicochemical and flour pasting properties of the maize varieties studied and the principal components are presented in Table 4. A correlation value above 0.3 is deemed significant. Thus, the first principal component is positively correlated with moisture content, peak 
viscosity, through viscosity, final viscosity and setback. The second principal component is also positively correlated with a* values, amylose content and pasting temperature and negatively correlated with $L^{*}$ values and protein contents. The third principal component is positively correlated with fat content and $\mathrm{a}^{*}$ values and negatively correlated with carbohydrates contents, a* and $\mathrm{b}^{*}$ values. The first two components in the PCA accounted for $50.5 \%$ and $15.5 \%$, respectively (in total $66 \%$ ) of the variation among varieties. The third component added $10.9 \%$ again, but was let. Thus, the observed variables of maize varieties were projected on the plane defined by the combination of axes first component and second component (Figure 2). Variables that are positively related are located in the same area of the plane. After the PCA, the individuals factor map (Figure 3) was used to predict the coordinates of the individuals. As can been easily observed, four groups of maize varieties were identified.

Group 1 represents all the improved varieties which were characterized by moisture contents, ash, crude fiber, carbohydrates, final viscosity, setback, peak time, amylose content and through viscosity higher than those of local varieties. Group 2 only constituted by Gnonli was characterized by the high lightness $\left(\mathrm{L}^{*}\right)$ and high protein contents. Gounvè, Tchèvè and Gbadé vovo in the Group 3 were characterized by the high redness $\left(a^{*}\right)$. These last varieties have also the high ash and high carbohydrates. All the other maize varieties have the high lightness $\left(\mathrm{L}^{*}\right)$ therefore the high yellowness $\left(\mathrm{b}^{*}\right)$. Group 4 gathering Kpatcha kpatcha, Fonkouin, and Tchankpo have also a lightness $\left(\mathrm{L}^{*}\right)$, protein contents and viscosity parameters higher than those of other local varieties.

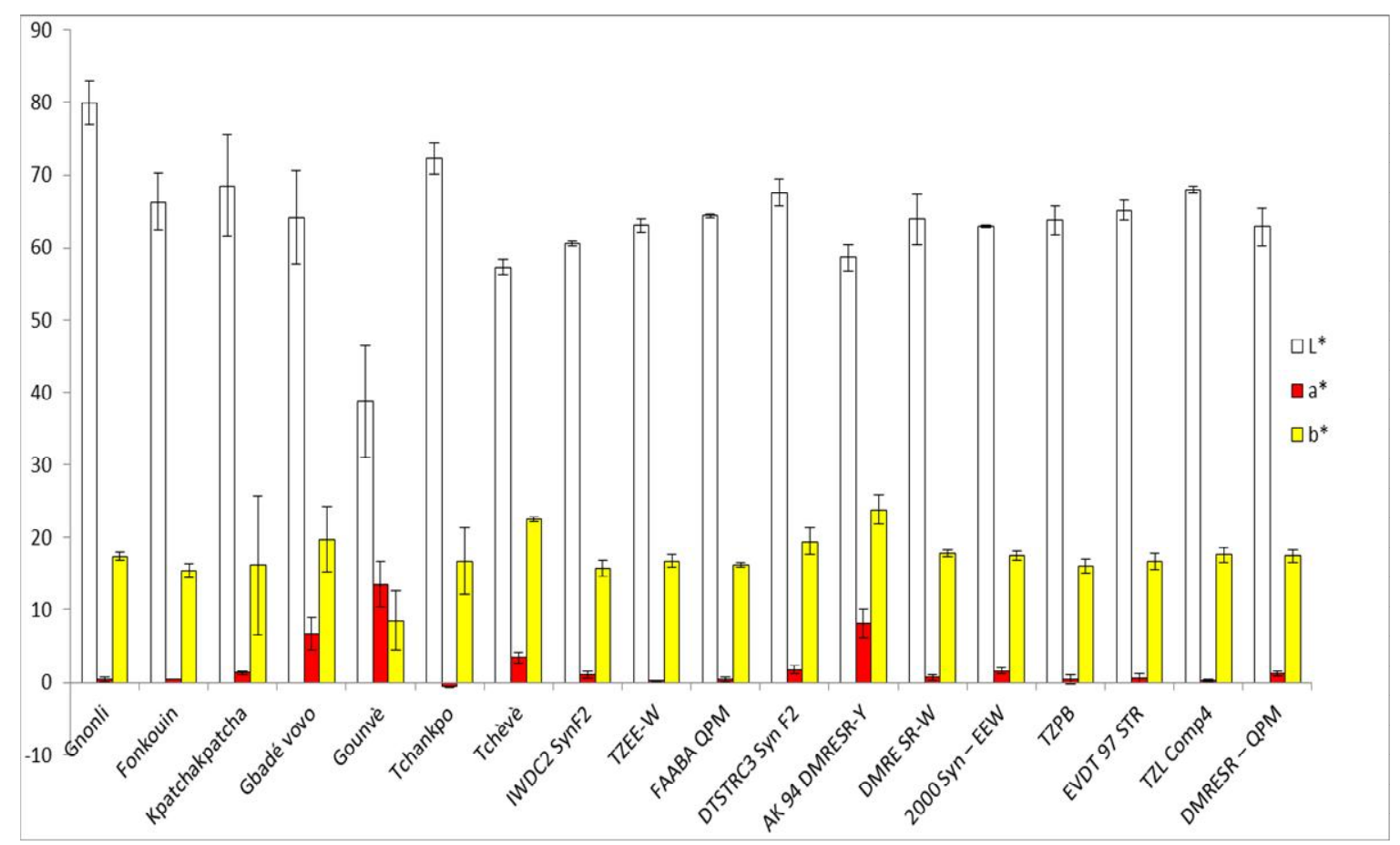

Figure 1: Color parameters of the different maize varieties. 
F. S. Y. SAGBO et al. / Int. J. Biol. Chem. Sci. 11(4): 1753-1765, 2017

Table 2: Proximate composition of maize varieties.

\begin{tabular}{|c|c|c|c|c|c|c|c|}
\hline Varieties & Moisture (\%) & Fat $(\%)$ & Protein (\%) & $\operatorname{Ash}(\%)$ & Fiber (\%) & Carbohydrates (\%) & Amylose (\%) \\
\hline Gnonli & $9.14 \pm 0.22^{\mathrm{c}}$ & $2.87 \pm 0.14^{\mathrm{a}}$ & $11.17 \pm 1.23^{\mathrm{a}}$ & $3.38 \pm 0.3^{\mathrm{c}}$ & $0.013 \pm 0^{\mathrm{a}}$ & $73.43 \pm 0.65^{\mathrm{ef}}$ & $22.58 \pm 2.69^{\mathrm{a}}$ \\
\hline Fonkouin & $7.70 \pm 0.06^{\mathrm{b}}$ & $4.50 \pm 0.96^{\mathrm{abc}}$ & $8.57 \pm 0.20^{\mathrm{ab}}$ & $3.41 \pm 0.13^{\mathrm{c}}$ & $0.013 \pm 0.002 \mathrm{a}$ & $75.81 \pm 1.02^{\mathrm{fg}}$ & $23.37 \pm 0.43^{\mathrm{a}}$ \\
\hline Kpatchakpatcha & $6.24 \pm 0.06^{\mathrm{a}}$ & $4.03 \pm 0.44^{\mathrm{ab}}$ & $9.34 \pm 0.06^{\mathrm{c}}$ & $3.54 \pm 0.05^{\mathrm{c}}$ & $0.017 \pm 0.001^{\mathrm{abc}}$ & $76.83 \pm 1.12^{\mathrm{fg}}$ & $23.45 \pm 2.25^{\mathrm{a}}$ \\
\hline Gbadévovo & $6.09 \pm 0.03^{\mathrm{a}}$ & $4.56 \pm 1.14^{\mathrm{abc}}$ & $9.07 \pm 0.61 b^{c}$ & $5.46 \pm 0.33^{\mathrm{e}}$ & $0.013 \pm 0.001^{\mathrm{a}}$ & $74.81 \pm 0.13^{\mathrm{fg}}$ & $25.53 \pm 0.53^{a}$ \\
\hline Gounvè & $7.26 \pm 0.42^{\mathrm{ab}}$ & $5.42 \pm 1.14^{\mathrm{abc}}$ & $8.98 \pm 0.43^{\mathrm{bc}}$ & $4.74 \pm 0.3^{\mathrm{d}}$ & $0.017 \pm 0.007^{\mathrm{ab}}$ & $73.58 \pm 0.06^{\mathrm{ef}}$ & $23.35 \pm 0.23^{\mathrm{a}}$ \\
\hline Tchankpo & $6.49 \pm 0.39^{\mathrm{a}}$ & $5.38 \pm 1.62^{\mathrm{abc}}$ & $9.53 \pm 0.27^{\mathrm{cd}}$ & $2.17 \pm 0.14^{\mathrm{b}}$ & $0.010 \pm 0.002^{\mathrm{a}}$ & $76.43 \pm 0.27^{\mathrm{fg}}$ & $23.54 \pm 0.17^{\mathrm{a}}$ \\
\hline Tchèvè & $7.87 \pm 0.17^{\mathrm{b}}$ & $4.24 \pm 0.15^{\mathrm{ab}}$ & $7.91 \pm 0.75^{\mathrm{ab}}$ & $1.69 \pm 0.06^{\mathrm{a}}$ & $0.014 \pm 0.001^{\mathrm{a}}$ & $78.28 \pm 1.31^{\mathrm{g}}$ & $24.59 \pm 0.3^{4 a}$ \\
\hline $\mathrm{IWDC}_{2} \mathrm{SynF}_{2}$ & $10.78 \pm 0.04^{\mathrm{d}}$ & $4.56 \pm 3.37^{\mathrm{ab}}$ & $8.51 \pm 0.04^{\mathrm{abc}}$ & $1.26 \pm 0.01^{\mathrm{a}}$ & $0.034 \pm 0.016^{\mathrm{bc}}$ & $74.71 \pm 0.05^{\mathrm{fg}}$ & $26.86 \pm 0.21^{\mathrm{a}}$ \\
\hline TZEE-W & $11.30 \pm 0.67^{\mathrm{d}}$ & $5.74 \pm 0.53^{\mathrm{abc}}$ & $7.53 \pm 0.04^{\mathrm{a}}$ & $1.34 \pm 0.01^{\mathrm{a}}$ & $0.021 \pm 0.002^{\mathrm{abc}}$ & $73.97 \pm 1.08^{f}$ & $25.15 \pm 0.48^{a}$ \\
\hline FAABA QPM & $10.94 \pm 1.14^{\mathrm{d}}$ & $9.29 \pm 0.61^{\text {bcde }}$ & $9.91 \pm 0.03^{\mathrm{cd}}$ & $2.13 \pm 0.01^{\mathrm{b}}$ & $0.027 \pm 0.001^{\mathrm{abc}}$ & $68.55 \pm 0.11^{\mathrm{bc}}$ & $26.03 \pm 0.67^{\mathrm{a}}$ \\
\hline DTSTRC $_{3}$ Syn $_{2}$ & $11.12 \pm 0.11^{\mathrm{d}}$ & $5.08 \pm 0.40^{\mathrm{abc}}$ & $9.842 \pm 0.06^{\mathrm{cd}}$ & $1.27 \pm 0.07^{\mathrm{a}}$ & $0.036 \pm 0.006^{\mathrm{c}}$ & $72.49 \pm 0.15^{\mathrm{de}}$ & $25.18 \pm 0.20^{\mathrm{a}}$ \\
\hline AK 94 DMRESR-Y & $10.05 \pm 0.55^{\mathrm{cd}}$ & $10.20 \pm 0.37_{\mathrm{bcde}}$ & $9.548 \pm 0.06^{\mathrm{cd}}$ & $1.36 \pm 0.02^{\mathrm{a}}$ & $0.022 \pm 0.002^{\mathrm{abc}}$ & $68.67 \pm 0.72^{\mathrm{bc}}$ & $25.09 \pm 1.94^{\mathrm{a}}$ \\
\hline DMRE SR-W & $10.38 \pm 0.07^{\mathrm{cd}}$ & $9.25 \pm 2.12^{\text {bcde }}$ & $8.733 \pm 0.01^{\mathrm{bc}}$ & $1.22 \pm 0.07^{\mathrm{a}}$ & $0.021 \pm 0^{\mathrm{abc}}$ & $70.27 \pm 0.18^{\text {cde }}$ & $24.69 \pm 0.33^{\mathrm{a}}$ \\
\hline 2000Syn - EEW & $10.45 \pm 0.21^{\mathrm{cd}}$ & $11.96 \pm 1.90^{\mathrm{de}}$ & $9.563 \pm 0.01^{\mathrm{cd}}$ & $1.09 \pm 0.01^{\mathrm{a}}$ & $0.025 \pm 0.001^{\mathrm{abc}}$ & $66.78 \pm 0.02^{\mathrm{ab}}$ & $24.86 \pm 0.37^{\mathrm{a}}$ \\
\hline TZPB & $10.69 \pm 0.41^{\mathrm{d}}$ & $10.71 \pm 0.25^{\text {cde }}$ & $10.750 \pm 0.01^{\mathrm{d}}$ & $2.51 \pm 0.32^{\mathrm{b}}$ & $0.027 \pm 0.009^{\mathrm{abc}}$ & $66.34 \pm 0.17^{\mathrm{ab}}$ & $24.46 \pm 0.17^{\mathrm{a}}$ \\
\hline EVDT97STR & $11.46 \pm 0.22^{\mathrm{d}}$ & $14.16 \pm 0.06_{\mathrm{e}}$ & $8.855 \pm 0.04^{\mathrm{bc}}$ & $1.48 \pm 0.07^{\mathrm{a}}$ & $0.025 \pm 0.001^{\mathrm{abc}}$ & $64.19 \pm 0.21^{\mathrm{a}}$ & $24.37 \pm 1.61^{\mathrm{a}}$ \\
\hline TZL Comp4 & $11.57 \pm 0.95^{\mathrm{d}}$ & $8.52 \pm 2.72_{\mathrm{ab}}$ & $9.544 \pm 0.04^{\mathrm{cd}}$ & $1.33 \pm 0.03^{\mathrm{a}}$ & $0.021 \pm 0.004^{\mathrm{ab}}$ & $68.84 \pm 2.72 b c$ & $23.28 \pm 1.68^{\mathrm{a}}$ \\
\hline DMRESR - QPM & $11.34 \pm 0.61^{\mathrm{d}}$ & $8.08 \pm 2.09^{\mathrm{ab}}$ & $9.493 \pm 0.03^{\mathrm{cd}}$ & $1.30 \pm 0.07^{\mathrm{a}}$ & $0.027 \pm 0.005^{\mathrm{abc}}$ & $69.58 \pm 0.07^{\mathrm{bcd}}$ & $23.76 \pm 0.37^{\mathrm{a}}$ \\
\hline
\end{tabular}


Table 3: Pasting properties of flours from maize varieties.

\begin{tabular}{|c|c|c|c|c|c|c|}
\hline Maize variety & $\begin{array}{c}\text { Peak viscosity } \\
\text { (cP) }\end{array}$ & $\begin{array}{c}\text { Trough viscosity } \\
\text { (cP) }\end{array}$ & $\begin{array}{l}\text { Final viscosity } \\
\text { (cP) }\end{array}$ & $\begin{array}{l}\text { Setback } \\
\text { (cP) }\end{array}$ & $\begin{array}{c}\text { Peak Time } \\
\text { (min) }\end{array}$ & Pasting Temperature $\left({ }^{\circ} \mathrm{C}\right)$ \\
\hline Gnonli & $453 \pm 4.24^{\mathrm{ab}}$ & $981 \pm 8.49^{\text {gh }}$ & $981 \pm 9.9^{b}$ & $388 \pm 12.73^{\mathrm{ab}}$ & $4.63 \pm 0.05^{\mathrm{a}}$ & $79.65 \pm 0.57^{b}$ \\
\hline Fonkouin & $438 \pm 4.24^{\mathrm{a}}$ & $439 \pm 4.24^{\mathrm{a}}$ & $800 \pm 4.24^{\mathrm{a}}$ & $362 \pm 0^{\mathrm{a}}$ & $7.00 \pm 0^{\mathrm{e}}$ & $78 \pm 0^{\mathrm{a}}$ \\
\hline Kpatchakpatcha & $593.5 \pm 6.36^{\mathrm{d}}$ & $594 \pm 5.66^{\mathrm{c}}$ & $1073 \pm 7.07^{\mathrm{c}}$ & $479.5 \pm 0.71^{\mathrm{b}}$ & $6.97 \pm 0.05^{\mathrm{e}}$ & $79.98 \pm 0.11^{\mathrm{b}}$ \\
\hline Gbadé vovo & $473.5 \pm 4.95^{\mathrm{bc}}$ & $474.5 \pm 4.95^{\mathrm{b}}$ & $919.5 \pm 12.02^{b}$ & $446 \pm 7.07^{\mathrm{b}}$ & $6.97 \pm 0.05^{\mathrm{e}}$ & $82.76 \pm 0.35^{\mathrm{de}}$ \\
\hline Gounvè & $504 \pm 1.41^{\mathrm{c}}$ & $503.5 \pm 2.12^{\mathrm{b}}$ & $911 \pm 5.66^{\mathrm{b}}$ & $407 \pm 4.24^{\mathrm{ab}}$ & $6.97 \pm 0.05^{\mathrm{e}}$ & $81.63 \pm 0.04^{\mathrm{c}}$ \\
\hline Tchankpo & $499.5 \pm 3.54^{\mathrm{c}}$ & $500.5 \pm 3.54^{b}$ & $941 \pm 1.41^{\mathrm{b}}$ & $415 \pm 4.95^{\mathrm{ab}}$ & $6.97 \pm 0.05^{\mathrm{e}}$ & $8238 \pm 0.04^{\text {cde }}$ \\
\hline Tchèvè & $479 \pm 1.41 \mathrm{bc}$ & $481 \pm 1.41^{\mathrm{b}}$ & $896 \pm 9.9^{b}$ & $417 \pm 8.49^{\mathrm{ab}}$ & $7.00 \pm 00^{\mathrm{e}}$ & $82.75 \pm 0.35^{\text {de }}$ \\
\hline $\mathrm{IWDC}_{2} \mathrm{SynF}_{2}$ & $1130.5 \pm 6.36^{\mathrm{k}}$ & $1008.0 \pm 19.80^{\mathrm{hi}}$ & $3261.5 \pm 20.51^{\mathrm{i}}$ & $2253.5 \pm 0.71^{\mathrm{h}}$ & $5.7 \pm 0^{\mathrm{d}}$ & $84.125 \pm 0.04^{\mathrm{f}}$ \\
\hline TZEE-W & $1085.5 \pm 4.95^{\mathrm{j}}$ & $971.5 \pm 23.33^{\mathrm{gh}}$ & $2912.5 \pm 12.02 \mathrm{~g}$ & $1941 \pm 11.31^{\mathrm{f}}$ & $5.3 \pm 0^{\mathrm{bc}}$ & $82.775 \pm 0.60^{\mathrm{de}}$ \\
\hline FAABA QPM & $823.5 \pm 14.85^{\mathrm{f}}$ & $820.0 \pm 14.14^{\mathrm{d}}$ & $2016.5 \pm 51.62^{\mathrm{e}}$ & $1196.5 \pm 37.48^{d}$ & $6.9 \pm 0.19^{\mathrm{e}}$ & $81.575 \pm 0.04^{\mathrm{c}}$ \\
\hline DTSTRC $_{3}$ Syn F $_{2}$ & $918.5 \pm 7.78^{\mathrm{g}}$ & $841.0 \pm 2.83^{\mathrm{e}}$ & $2849 \pm 11.31^{\mathrm{fg}}$ & $2008 \pm 8.49^{f}$ & 5. $5 \pm 0^{\mathrm{c}}$ & $85.775 \pm 0.04^{\mathrm{h}}$ \\
\hline AK 94 DMRESR-Y & $1091.5 \pm 30.41^{\mathrm{j}}$ & $956.0 \pm 2.83^{\mathrm{g}}$ & $3490 \pm 16.97^{\mathrm{jk}}$ & $2534 \pm 14.14^{\mathrm{k}}$ & 5. $4 \pm 0.05^{\mathrm{bc}}$ & $85.825 \pm 0.18^{\mathrm{h}}$ \\
\hline DMRE SR-W & $1271.5 \pm 7.78^{\mathrm{m}}$ & $1036.5 \pm 10.61^{\mathrm{i}}$ & $3521.5 \pm 12.02^{\mathrm{k}}$ & $2485 \pm 22.63^{\mathrm{jk}}$ & $5.3 \pm 0^{\mathrm{bc}}$ & $83.275 \pm 0.04^{\mathrm{e}}$ \\
\hline 2000 Syn - EEW & $1220 \pm 12.731^{\mathrm{k}}$ & $1009.5 \pm 17.68^{\mathrm{hi}}$ & $3428.5 \pm 82.73^{\mathrm{j}}$ & $2419 \pm 65.05^{\mathrm{j}}$ & $5.3 \pm 0.09^{\mathrm{bc}}$ & $83.225 \pm 0.04^{\mathrm{e}}$ \\
\hline TZPB & $760.5 \pm 28.99^{\mathrm{e}}$ & $752.0 \pm 31.11$ & $1752.5 \pm 81.32^{\mathrm{d}}$ & $1000.5 \pm 50.20^{\mathrm{c}}$ & $5.5 \pm 0.09^{c}$ & $81.625 \pm 0.04^{\mathrm{c}}$ \\
\hline EVDT 97 STR & $1237 \pm 16.971^{1}$ & $1066.0 \pm 19.80^{\mathrm{f}}$ & $3398 \pm 76.37^{j}$ & $2332 \pm 96.17^{\mathrm{i}}$ & $5.2 \pm 0.05^{\mathrm{b}}$ & $82 \pm 0.57^{\mathrm{cd}}$ \\
\hline TZL Comp4 & $1044.5 \pm 4.95^{\mathrm{i}}$ & $923.0 \pm 0^{\mathrm{f}}$ & $2776.5 \pm 2.12^{f}$ & $1853.5 \pm 2.12^{\mathrm{e}}$ & $5.2 \pm 0.05^{\mathrm{b}}$ & $82.025 \pm 0.60^{\mathrm{cd}}$ \\
\hline DMRESR - QPM & $992.5 \pm 10.61^{\mathrm{h}}$ & $916.5 \pm 13.44^{j}$ & $3048 \pm 2.83^{h}$ & $2131.5 \pm 10,61^{\mathrm{g}}$ & $5.4 \pm 0.05^{\mathrm{bc}}$ & $84.875 \pm 0.04^{\mathrm{g}}$ \\
\hline
\end{tabular}

Means with different superscript letters implies least significant difference at the 0.05 level of significance using one-way Analysis of variance 
Table 4: Correlation matrix between determined variables and the principal components.

\begin{tabular}{lccc}
\hline Variables & \multicolumn{3}{c}{ Principal Component } \\
\cline { 2 - 4 } & $\mathbf{1}$ & $\mathbf{2}$ & $\mathbf{3}$ \\
\hline Moisture contents & 0.320 & -0.073 & 0.066 \\
Fat & 0.246 & -0.009 & 0.337 \\
Protein & 0.014 & -0.393 & 0.294 \\
Ash & -0.290 & 0.043 & 0.245 \\
Fiber & 0.271 & 0.121 & 0.028 \\
Carbohydrates & -0.261 & 0.103 & -0.419 \\
Amylose & 0.156 & 0.338 & -0.267 \\
Peak 1 & 0.335 & 0.081 & 0.016 \\
Trough 1 & 0.318 & -0.134 & 0.044 \\
Final Viscosity & 0.341 & 0.089 & -0.018 \\
Setback & 0.338 & 0.105 & -0.030 \\
Peak Time & -0.271 & 0.244 & -0.074 \\
Pasting Temperature & 0.220 & 0.304 & -0.197 \\
L* & 0,025 & $-0,552$ & $-0,312$ \\
a* & $-0,109$ & 0,444 & 0,309 \\
b* & 0,101 & $-0,042$ & $-0,498$ \\
\hline A correlation value above 0.3 is deemed significant. & & &
\end{tabular}

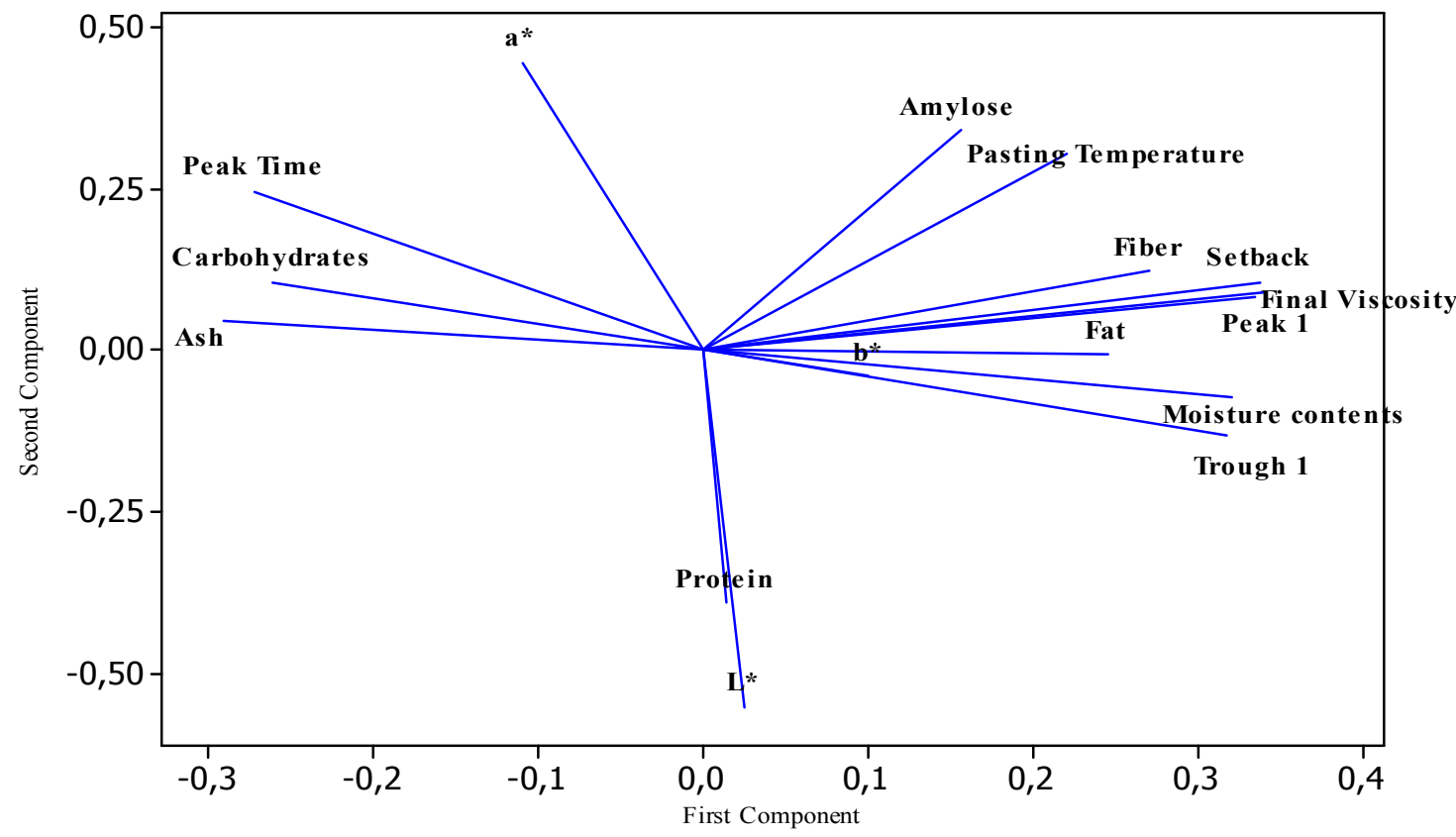

Figure 2: Loading Plot from Principal Component Analysis of physicochemical parameters and pasting properties of maize varieties. 


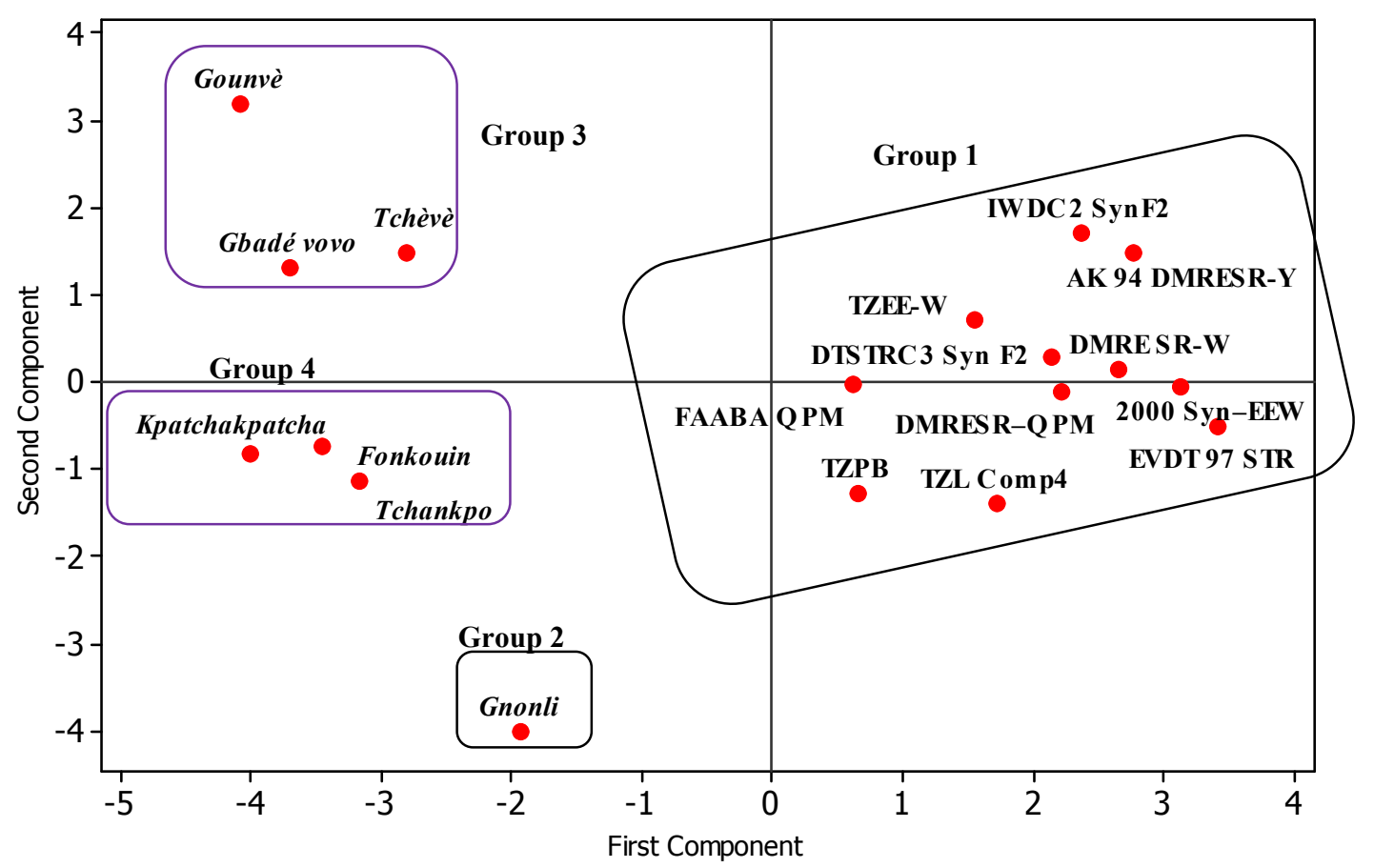

Figure 3: Individuals factor map obtained from the principal component analysis.

\section{DISCUSSION}

A comparative evaluation of the physicochemical and pasting properties of local and improved maize varieties cultivated in Benin was performed in this study. The grain color is one of criteria followed by consumers to choose a maize variety (Sagbo et al., 2016). In the present study, the grain color of local and improved maize varieties was evaluated. Thus, according to the $L^{*}, a^{*}$ and $b^{*}$ color components, three groups of varieties were distinguished. A group assembled the most white varieties Gnonli, Tchankpo, Fonkouin, Kpatchatcha, TZEE-W, FAABA, QPM, DTSTRC3, Syn F2, DMRE SR-W, 2000Syn-EEW, TZPB, EVDT 97 STR, TZLcomp4 and DMRESR-QPM. The second group, more yellow-reddish brought together varieties AK-94 DMRESR Y, Tchèvè and Gbadé vovo. The last group was formed by the only one variety Gounvè which is red. Most of the improved varieties were white. These results are consistent with those obtained by Yallou et al. (2010). Chromacity intensity differences have been associated to pigment levels in different vegetables (Carvalho et al., 2005). The reddish colors of maize varieties indicate the presence of carotenoids and anthocyanins. They can be oriented in the production of baby food due to their potential high level of $\beta$-carotene. The $a^{*}$ and $b^{*}$ values in the current study was lower than the findings of de Pinho et al. (2011) on green maize varieties. But the results, confirmed as reported by Pereira Filho et al. (2003) that the maize color may vary as a function of genetic origin and others factors. The different maize varieties showed a slightly variation in proximate composition in terms of moisture content, ash, lipids, protein 
content, crude fiber, carbohydrates. A low moisture content of grains is an advantage during storage for a long time. In this study, the local varieties had the lowest moisture contents and the improved varieties had the highest. These local varieties can thus be kept better. The levels of the aforementioned components of the proximate composition in this study have been similar to those observed from other studies in West Africa (Iken et al., 2002, Elenga et al., 2009, Enyisi et al., 2014, Ndukwe et al., 2015, Songre-Ouattara et al., 2015). Several authors reported on different maize varieties in Nigeria. Perhaps, this country bordering Benin Republic has similar maize varieties just named differently. In fact, a lot of improved varieties like TZPB, DMRESR-QPM and AK-94 DMRESR Y, investigated in this study and TZPB-SR-W, BR-9928-DMR-SRY and BR-9943-DMRSRW studied by Ndukwe et al. (2015) have their names closely related. The levels of amylose content found in this study are similar to those from other authors. Indeed, Seetharaman et al. (2001) reported amylose contents varying between 16.1 and $23.3 \%$ after analysis of 35 different varieties of maize. Sandhu et al. (2004) observed amylose contents ranged between 15.3 and $25.1 \%$. Starches of certain varieties are composed primarily of amylopectin, whereas others are much richer in amylose (Rahman et al., 2007). The results also showed that there is an interaction between some physicochemical components. There are significant amounts of data on the chemical composition of maize varieties found in West Africa, particularly in Nigeria and Benin but little is known on their pasting properties. This was determined in the current study in order to evaluate the behaviour of the starches during the heat treatments which result from the modifications of the internal structure of the granules. Pasting properties of maize flour from local and improved varieties differed. It depends on various chemical components of grain as well as the interactions of these components. This was previously reported by Tshite et al. (2015) who observed, when precooked flour with maize and soya beans were formulated, the proteins content was correlated with the viscosity and strongly correlated with ash. The results of this study showed that the pasting properties were more affected by the moisture content of the grains rather than color components, amylose and protein contents content. According to Zilic et al. (2011), it seems that the pasting properties were more influenced by starch type and quantity rather than protein presence. In our study, final viscosities of maize varieties were higher than peak viscosities. Ballogou et al. (2015) reported similar results on fonio. With the yam starch, Ayernor (1985) explains that the significantly higher value of the final viscosity in relation to the maximum viscosity may be due to a high degree of association between starch and water and their high recrystallization capacity implying in a gradually high viscosity during the cooling of the starch. Final viscosity indicates stability of the cooked dough (Liang and King, 2003). Baked dough obtained from local varieties may be more stable than those given by improved varieties. Setback represents the degree of retrogradation of the starch (Liang and King, 2003). Retrogradation represents changes in the structure of the granules and their dispersion medium during the cooling of starch pastes (Malumba Kamba, 2008). Retrogradation depends on several parameters, including the amylose and amylopectin structure, amylose / amylopectin ratio, starch concentration, botanical origin and concentration of other constituents of the medium (Jacobson et al., 1997). Setback of different maize varieties was high. The pasting properties measured were higher than results obtained with commercial maize and 
improved QPM maize in Nigeria tested by Edema et al. (2005).

\section{Conclusion}

The present study evaluated physicochemical and pasting properties of local and improved maize varieties cultivated in Benin. From the results obtained, it can be concluded that local and improved maize varieties cultivated in Benin contain a wealth of benefits, including good opportunities for improving nutrition, and multiple uses of maize and maize products. Local varieties may be oriented in the infant food industry. Improved varieties can be used in the starch manufacturing industry due to their high amylose content and higher viscosity values. AK 94 DMRESR-Y, Gounvè, Tchèvè and Gbadé vovo with their high ash content can be used in the production of food for children or malnourished person.

\section{COMPETING INTERESTS}

The authors declare that they have no competing interests.

\section{AUTHORS' CONTRIBUTIONS}

FSYS conducted the study, was responsible for data analysis and wrote the manuscript; MVA and WAH contributed in the design of the study and participated in the data interpretation and in the writing of the manuscript, $\mathrm{CH}$ assisted in the laboratory analysis, $\mathrm{AD}$ assisted in the conception of the study. MMS contributed in the design of the study, participated in the data interpretation and communicated with the journal. All authors have made their contribution in editing the manuscript and approved the final version.

\section{REFERENCES}

AOAC. 1990. Official Methods of Analysis of the AOAC (15th edn). Association of official Analytical Chemists: Arlington, USA.

Ayernor GS 1985. The Yam (Dioscorea) Starches. In Advances in Yam Research ( $1^{\text {st }}$ edn). Godson Osuji. Anambra State University of Technology Publishers: Nigeria, 79-88.

Ballogou VY, Sagbo FS, Soumanou MM, Manful JT, Toukourou F, Hounhouigan JD. 2015. Effect of processing method on physico-chemical and functional properties of two fonio (Digitaria exilis) landraces. J Food Sci Technol., 52(3): 1570-1577. DOI: http://dx.doi.org/ 10.1007/s13197-013-1150-4

Carvalho W, Fonseca' ME, da Silva' HR, Boiteux LS, Giordano L. 2005. Estimativa indireta de teores de licopeno em frutos de genótipos de tomateiro via análise colorimétrica. Horticultura Brasileira, 23(3): 819-825. DOI : http://dx.doi.org/10.1590/S010205362005000300026

Cissé M, Zoue LT, Soro YR, Megnanou R, Niamke S. 2013. Physicochemical and functional properties of starches of two quality protein maize (QPM) grown in Côte d'Ivoire. J. Appl. Biosci., 66: 51305139. DOI : http://dx.doi.org/ 10.4314/jab.v66i0.95010.

de Pinho L, Paes MCD, Glória MBA, Almeida AC, Costa CA. 2011. Color and chemical composition and of green corn produced under organic and conventional conditions. Ciênc. Tecnol. Aliment. Campinas, 31(2): 366-371. DOI: http://dx.doi.org/10.1590/S010120612011000200014

Edema MO, Sanni LO, Sanni AI. 2005. Evaluation of maize-soybean flour blends for sour maize bread production in Nigeria. African Journal of Biotechnology, 4(9): 911-918. 
Elenga M, Massamba J, Kobawila SC, Makosso VG, Silou T. 2009. Evaluation et amélioration de la qualité nutritionnelle des pâtes et des bouillies de maïs fermenté au Congo. Int. J. Biol. Chem. Sci., 3(6): 1274-1285.

Enyisi IS, Umoh VJ, Whong CMZ, Abdullahi IO, Alabi O. 2014. Chemical and nutritional value of maize and maize products obtained from selected markets in Kaduna State, Nigeria. African Journal of Food Science and Technology, 5(4): 100-104. DOI: http://dx.doi.org/10.14303/ajfst.2014.029

FAO. 2016. Produire plus avec moins en pratique : le maïs, le riz, le blé, Guide pour une production céréalière durable $120 \mathrm{p}$.

Horstmann SW, Belz MCE, Heitmann M, Zannini E, Arendt EK. 2016. Fundamental study on the impact of gluten-free starches on the quality of gluten-free model breads. Foods, 5(2): 30. DOI: http://dx.doi.org/10.3390/ foods 5020030

Iken JE, Amusa NA, Obatolu VO. 2002. Nutrient Composition and weight evaluation of some newly developed maize varieties in Nigeria. Journal of Food Technology in Africa, 7: 27-29. DOI: http://dx.doi.org/10.4314/ jfta.v7i1.19315

Jacobson MR, Obanni M, Bemeiller JN. Retrogradation of starches from different botanical sources (1997). Cereal Chemistry, 74: 511-518. DOI: http://dx.doi.org/10.1094/CCHEM.1997. 74.5 .511

Jompuk C, Cheuchart P, Jompuk P, Apisitwanich S. 2011. Improved tryptophan content in maize with opaque-2 gene using Marker Assisted Selection (MAS) in backcross and selfing generations. Kasetsart J. Nat. Sci. 45: 666-674.
Juliano BO. 1971. A simplified assay for milled-rice amylose. Cereal Sci. Today, 16: $334-338$.

Karim AA, Norziah MH, Seow CC. 2000. Methods for the study of starch retrogradation. Food Chem., 71(1): 9-36. DOI: $\quad$ https://doi.org/10.1016/S03088146(00)00130-8

Liang XM, King JM. 2003. Pasting and crystalline property differences of commercial and isolated rice starch and added amino acids. Journal of Food Science, 68(3): 832-838. DOI: https://doi.org/10.1111/j.13652621.2003.tb08251.x

Malumba Kamba P. 2008. Influence of drying temperatures on the techno-functional properties of corn. $\mathrm{PhD}$ thesis. Gembloux Agricultural University, Gembloux. p. 212.

Ndukwe OK, Edeoga HO, Omosun G. 2015. Varietal differences in some nutritional composition of ten maize (Zea mays L.) varieties grown in Nigeria. International Journal of Academic Research and Reflection, 3(5): 1-10.

Pereira Filho IA, Cruz JC, Gama EEG. 2003. Cultivares para consumo verde. In $O$ Cultivo do milho-verde Pereira Filho IA. (ed.). Informações Tecnológicas: Brasília, DF: Embrapa; 17-30.

Rahman S, Bird AR, Regina A, Morell M, 2007. Resistant starch in cereals: Exploiting genetic engineering and genetic variation. J. Cereal Sci., 46: 251260. DOI: http://dx.doi.org/10.1016/ j.jcs.2007.05.001

Sagbo FYS, Aïssi MV, Dansi A, Soumanou MM. 2016. Perception de la diversité, des choix et de l'aptitude à la transformation des écotypes de maïs cultivés au Bénin. J. Appl. Biosci., 104: 9992-10004.

Sandhu KS, Singh N, Kaur M, 2004. Characteristics of the different corn types 
and their grain fractions: Physicochemical, thermal, morphological, and rheological properties of starches. J. Food Eng., 64: 19-127. DOI: http://dx.doi.org/10.1016/ j.jfoodeng.2003.09.023

Sarr B, Kafando L, Atta S. 2011. Identification des risques climatiques de la culture du maïs au Burkina Faso. Int. J. Biol. Chem. Sci., 5(4): 1659-1675. DOI http://dx.doi.org/10.4314/ijbcs.v5i4.28

Seetharaman K, Tziotis A, Borras F, White PJ, Ferrer M, Robutti J. 2001. Thermal and functional characterization of starch from Argentinean corn. Cereal Chem., 78: $\quad 379-386 . \quad$ DOI: https://doi.org/10.1094/CCHEM.2001.78 .4 .379

Semassa JA, Anihouvi VB, Adjanohoun A, Padonou W, Gbénou J, Baba-Moussa L 2016. Physical and technological parameters of maize varieties (Zea mays L.) grown in the Southern parts of Benin and the influence of chemical Composition. Food and Nutrition Sciences, 7: 1386-1400. DOI: http://dx.doi.org/10.4236/fns.2016.71412 6

Singh N, Singh J, Kaur L, Sodhi NS, Gill BS. 2003. Morphological thermal and rheological properties of starches from different botanical sources. Food Chem., 81: 219-231. DOI: https://doi.org/ 10.1016/S0308-8146(02)00416-8

Sodjinou E, Adegbola PY, Zinsou J, Oloukoi L. 2008. Rice and Maize Stratification for Investment Decision Support. Agricultural Policy Analysis Program of the National Agricultural Research
Institute of Benin (PAPA/INRAB), and Rice Policy and Development Program, Research Division, Africa Rice Center, Cotonou; 117.

Songre-ouattara LT, Bationo F, Parkouda C, Dao A, Bassole IHN, Diawara B. 2015. Qualité des grains et aptitude à la transformation : cas des variétés de Sorghum bicolor, Pennisetum glaucum et Zea mays en usage en Afrique de l'Ouest. Int. J. Biol. Chem. Sci., 9(6): 2819-2832. DOI: http://dx.doi.org/ 10.4314/ijbcs.v9i6.23

Tshite FN., Mulamba VT, Ndianabo MJT .2015. Mise au point d'une farine précuite à base de maïs (Zea mays) et de soja (Glycine max) par la méthode traditionnelle. Int. J. Biol. Chem. Sci., 9(6): 2608-2622. DOI : http://dx.doi.org/10.4314/ijbcs.v9i6.8

Yallou CG, Aïhou K, Adjanohoun A, Baco MN, Sanni OA, 2010. Itinéraires techniques de production de semences de pré base, de base et certifiées de qualité des variétés de maïs. Dépôt légal $\mathrm{N}^{\circ}$ 4921 du 03/12/2010, du 4ème trimestre, Bibliothèque Nationale $(\mathrm{BN})$ du Bénin, p.22.

Zilic S, Milasinovic M, Terzic D, Barac M, Ignjatovic-Micic D. 2011. Grain characteristics and composition of maize specialty hybrids. Span J Agric Res., 9(1): 230-241.DOI: http://dx.doi.org/ 10.5424/sjar/20110901-053-10 